\title{
Myasthenia gravis and thymus: long-term follow-up screening of thymectomized and non-thymectomized patients
}

\author{
Miastenia gravis e timo: investigação no seguimento de longo \\ prazo em pacientes timectomizados e não timectomizados \\ Paulo José Lorenzoni, Lucas Pires Augusto, Cláudia Suemi Kamoi Kay, Rosana Herminia Scola, \\ Lineu Cesar Werneck
}

\begin{abstract}
Thymoma screening is recommended at the onset of myasthenia gravis (MG) or when patients with MG present with clinical deterioration or a progressive increase of anti-acetylcholine receptor antibody. However, it is unknown if it is necessary to repeat the screening of thymoma at fixed intervals, even in the absence of MG deterioration, when the initial screening is negative. We analyzed the recurrence rate and incidence of new thymoma in a series of patients with well-controlled MG. The sample consisted of 53 patients, aged 17 to 72 years, and the follow-up varied between 75 and 472 months. The chest computerized tomography detected thymus abnormalities in eight patients at the initial screening and no abnormalities in all patients at a second screening after five years. The findings of this study support the classical opinion that screening for thymoma should be recommended only if there is clinical deterioration due to the disease.
\end{abstract}

Keywords: myasthenia gravis, thymus gland, thymoma, tomography.

\section{RESUMO}

A investigação de timoma é recomendada em pacientes com miastenia gravis (MG) no início da doença, em caso de haver piora clínica ou aumento dos níveis do anticorpo antirreceptor de acetilcolina. Contudo, não foi estabelecido se é necessário repetir a investigação de timoma em intervalos fixos, na ausência de piora clínica, quando a investigação inicial foi negativa. A taxa de recorrência e a incidência de novo timoma foram analisadas em uma série de pacientes com MG bem controlada. A amostra consiste de 53 pacientes, idade entre 17 e 72 anos, com tempo de acompanhamento variando entre 75 e 472 meses. A primeira tomografia computadorizada de tórax detectou anormalidades no timo em oito pacientes durante a investigação inicial da doença e nenhuma anormalidade no segundo exame, após cinco anos de doença, em todos os pacientes. Os achados desse estudo corroboram a clássica opinião de que a investigação de timoma deveria ser recomendada somente se houver piora clínica da doença.

Palavras-Chave: miastenia gravis, timo, timoma, tomografia.

Thymoma is strongly associated with myasthenia gravis (MG), particularly at the onset of the disease ${ }^{1}$. Thymus investigation in MG patients is typically recommended at the onset of MG or when patients present with clinical deterioration or a progressive increase of anti-acetylcholine receptor (AChR) antibody ${ }^{2,3}$.

However, it is unknown if repeated screenings for thymoma at fixed intervals, even in the absence of MG deterioration, are necessary when the initial screening is negative. In addition, therapeutic guidelines do not mention the importance of thymus follow-up if the initial screening is negative ${ }^{1,4}$.
The main objective of this study was to determine the recurrence rate and incidence of new thymoma in a series of MG patients without clinical deterioration who underwent long-term follow-up.

\section{METHODS}

We included MG patients who fulfilled the following criteria: (1) diagnosis based on abnormal repetitive nerve

Study carried out at Hospital de Clínicas, Universidade Federal do Paraná (UFPR), Curitiba PR, Brazil.

Neuromuscular Disorders Service, Neurology Division, Internal Medicine Department, Hospital de Clínicas, UFPR, Curitiba PR, Brazil.

Correspondence: Rosana Herminia Scola; Serviço de Doenças Neuromusculares, Hospital de Clínicas da UFPR; Rua General Carneiro 181 / 30 andar; $80060-900$ Curitiba PR - Brasil; E-mail:scola@hc.ufpr.br

Conflict of interest: There is no conflict of interest to declare.

Received 29 November 2012; Received in final form 05 March 2013; Accepted 12 March 2013. 
stimulation (RNS) and/or presence of anti-AChR antibody; (2) follow-up for more than five years; (3) well-controlled disease; (4) a first contrast-enhanced chest computerized tomography (CT) at the beginning of the disease; and (5) a second contrast-enhanced chest CT after five years. MG was considered well-controlled if the patients had pharmacological remission or minimal manifestations of disease, according to the Myasthenia Gravis Foundation of America's (MGFA) clinical classification standard 4 .

Relevant data, including age, gender, clinical status, serum anti-AChR antibody levels, RNS findings, thymus histopathology and treatment, were recorded at the second chest CT screening. To measure the clinical status of the patients, MG composite (MGC) was performed at the second chest CT screening ${ }^{5}$.

MG patients were classified according previous thymectomy status into the thymectomized group (TG) and the non-thymectomized group (NTG).

All studies were conducted after obtaining patient consent in the out-patient clinic or during hospital admission for diagnostic investigation.

Table. Characteristics of thymectomized and non-thymectomized groups of myasthenia gravis patients $(n=53)$.

\begin{tabular}{|c|c|c|c|}
\hline & $T G(n=21)$ & NTG $(n=32)$ & Total $(n=53)$ \\
\hline Gender (F:M) & $9.5: 1$ & $3.5: 1$ & $4.9: 1$ \\
\hline \multicolumn{4}{|l|}{ Age (years) } \\
\hline Mean $\pm S D$ & $42.1 \pm 10.38$ & $42 \pm 12.34$ & $42.1 \pm 11.50$ \\
\hline Median (range) & $43(25-59)$ & $41.5(17-72)$ & $41.8(17-72)$ \\
\hline \multicolumn{4}{|c|}{ Follow-up time (month) } \\
\hline Mean $\pm S D$ & $197.7 \pm 116.68$ & $171.7 \pm 81.66$ & $182.2 \pm 96.99$ \\
\hline Median (range) & $180(75-472)$ & $159.5(88-364)$ & $170(75-472)$ \\
\hline \multicolumn{4}{|l|}{ MGFA class* } \\
\hline I & 13 & 15 & 28 \\
\hline $\mathrm{Ila}$ & 5 & 16 & 21 \\
\hline $\mathrm{Ilb}$ & 3 & 1 & 4 \\
\hline \multicolumn{4}{|l|}{ MG Composite } \\
\hline Mean $\pm S D$ & $3.6 \pm 4.04$ & $4.09 \pm 3.79$ & $3.83 \pm 3.87$ \\
\hline Median (range) & $3(0-13)$ & $4(0-12)$ & $3(0-13)$ \\
\hline Abnormal RNS & 19 & 28 & 47 \\
\hline $\begin{array}{l}\text { Anti-AChR } \\
\text { antibody**}\end{array}$ & 8/11 & $20 / 23$ & $28 / 34$ \\
\hline \multicolumn{4}{|c|}{ Abnormal Chest CT*** } \\
\hline Initial screening & 8 & 0 & 8 \\
\hline After 5 years & 0 & 0 & 0 \\
\hline \multicolumn{4}{|c|}{ Thymus histopathology } \\
\hline Thymoma & 8 & 0 & 8 \\
\hline Hyperplasia & 8 & 0 & 8 \\
\hline Normal & 5 & 0 & 5 \\
\hline \multicolumn{4}{|c|}{ Treatment at investigation } \\
\hline Pyridostigmine & 21 & 31 & 52 \\
\hline Prednisone & 21 & 29 & 50 \\
\hline Azathioprine & 20 & 26 & 46 \\
\hline
\end{tabular}

TG: thymectomized group; NTG: non-thymectomized group; F: female; M: male; SD: standard deviation; MGFA: Myasthenia Gravis Foundation of America; MG: myasthenia gravis; RNS: repetitive nerve stimulation; AChR: acetylcholine receptor; CT: computerized tomography; *MGFA clinical classification; ** number of positive patient/number of performed test; $* * \star$ detected thymoma.

\section{RESULTS}

The sample consisted of 53 patients (44 female and 9 male), aged 17 to 72 years (median 41.8 years; mean $42.1 \pm 11.50$ years). There were $21 \mathrm{TG}$ patients $(39.6 \%)$ and 32 NTG (60.4\%). The duration of follow-up in our hospital varied between 75 and 472 months, with a mean time of 182.2 \pm 96.99 months. MGFA classification revealed 52.8\% of patients in class I, $39.6 \%$ in class IIa and $7.5 \%$ in class IIb. The MGC varied between 0 and 13, with a mean of 3.83 \pm 3.87 .

Serological analysis was performed in 34 patients; serum anti-AChR antibody (binding type) was present in $82.35 \%$.

The RNS test was abnormal in $88.67 \%$ and normal in the remaining $11.33 \%$.

The chest CT detected thymus abnormalities in 8 patients $(16.3 \%)$ at the initial screening and the absence of thymus abnormalities at the second screening in all patients after 5 years. The 8 patients with abnormalities in the initial screening had a mean age of $46.12 \pm 9.65$ years and a mean follow-up of $203.75 \pm 154.86$ months. In these patients, the most common chest CT findings detected were thymoma at the initial screening (100\%) and the absence of thymus abnormalities compatible with thymoma at the second screening (100\%).

Twenty-one patients were thymectomized for thymoma or management of disease symptoms. Thymus histopathology revealed thymoma in 8 patients, thymic hyperplasia in 8 and no abnormalities in 5 . The suspicion of thymoma in 8 patients based on the initial chest CT screening (16.3\%) was confirmed in all 8 by histopathological study.

The drugs used for MG treatment at the second chest CT screening were pyridostigmine in $98.11 \%$ of patients, prednisone in $94.33 \%$ and azathioprine in $86.79 \%$.

Table shows the differences between the TG and NTG groups.

\section{DISCUSSION}

In the present study, we did not find any recurrence of thymoma in $\mathrm{MG}$ patients with previous thymectomy or new thymoma after at least five years in $M G$ patients without thymectomy. The MGFA classification and MGC score showed that for our patients MG was well-controlled at the time the second chest $\mathrm{CT}$ was performed ${ }^{4,5}$. This finding suggests that screening for thymoma after five years of follow-up is not necessary for patients with well-controlled MG.

Thymoma recurrences are often associated with the onset or aggravation of $\mathrm{MG}^{1,2,6}$. In addition, the complete surgical resection of thymoma has been reported as the only significant independent prognostic factor influencing thymoma recurrence in previously thymectomized MG patients ${ }^{1,7} . M G$ in our patients with previous thymoma was well controlled, and they had undergone complete surgical 
resection. This could help explain the absence of tumor recurrence in our cases.

Chest CT is currently considered the first choice for the screening of thymoma. It has been stated that chest CT scans should be conducted yearly for the first 2, 5 or 10 years following the initial thymectomy and every 2 years afterwards, especially in thymomatous patients ${ }^{2,7,8}$. However, routine screening of thymoma in well-controlled MG patients is rarely discussed in the literature ${ }^{3}$.

High-doses of steroids were previously reported to reduce the size of invasive thymoma, indicating that the growth of a thymoma also depends on steroids ${ }^{9}$. We did not describe patient steroid doses, but almost all of them used $1 \mathrm{mg} / \mathrm{kg} /$ day of prednisone at the beginning of the disease. This could have influenced our findings; however, we cannot analyze the relationship between steroids and thymoma because we did not observe thymoma in our sample. Despite the absence of new thymoma in our subjects, cases of new thymoma have been reported in patients using steroids ${ }^{3}$.

Other characteristics of MG patients associated with thymoma, such as an abnormal RNS or the presence of AChR antibody, could be useful in screening for recurrent or new thymoma. This study and other studies have not established this correlation. However, some MG patients have other antibodies that bind in a cross-striational pattern to skeletal and heart muscle tissue sections (striational antibodies) ${ }^{10}$. Striational antibodies that react with epitopes on the muscle proteins titin, ryanodine receptor (RyR), and voltage-gated potassium receptor (Kv1.4) are expressed in the thymoma tissue of $\mathrm{MG}$ patients ${ }^{10}$. Clinically, the presence of striational antibodies and CT scans of the anterior mediastinum show a similar sensitivity for screening of thymoma in MG patients ${ }^{10}$. The frequencies of striational antibodies are generally high in MG patients with thymoma, but these antibody assays could not be performed in our patients.

The clinical presentation of MG and its course and outcome are highly dependent on thymus pathology and antibody status. The findings of this study support the classical opinion that screening for thymoma should be recommended only if there is clinical deterioration associated with the disease. However, we also speculate that the detection of striational antibodies, associated with chest CT screening, could provide more specific information about subgroups of well-controlled MG patients, including the recurrence rate or chance of new thymoma during long-term follow-up.

\section{References}

1. Zielinski M. Management of myasthenic patients with thymoma. Thorac Surg Clin 2011;21:47-57.

2. Evoli A, Minisci C, Di Schino C, et al. Thymoma in patients with MG: characteristics and long-term outcome. Neurology 2002;59: 1844-1850.

3. Sugawara M, Wada C, Okawa S, et al. Long-term follow up of thymus in patients with myasthenia gravis. J Neuroimmunol 2010;221:121-124.

4. Jaretzki 3rd A, Barohn RJ, Ernstoff RM, et al. Myasthenia gravis: recommendations for clinical research standards. Task Force of the Medical Scientific Advisory Board of the Myasthenia Gravis Foundation of America. Ann Thorac Surg 2000;70:327-334.

5. Burns TM, Conaway M, Sanders DB. The MG Composite: a valid and reliable outcome measure for myasthenia gravis. Neurology 2010;74:1434-1440.
6. Kondon K, Monden Y. Thymoma and myasthenia gravis: a clinical study of 1,089 patients from Japan. Ann Thorac Surg 2005;79: 219-224.

7. Margaritora S, Cesario A, Cusumano G, et al. Thirty-five-year followup analysis of clinical and pathologic outcomes of thymoma surgery. Ann Thorac Surg 2010;89:245-252.

8. Margaritora S, Cesario A, Cusumano G, et al. Single-centre 40-year results of redo operation for recurrent thymomas. Eur $\mathrm{J}$ Cardiothorac Surg 2011;40:894-900.

9. Kirkove C, Berghmans J, Noel H, van de Merckt J. Dramatic response of recurrent invasive thymoma to high doses of corticosteroids. Clin Oncol (R Coll Radiol) 1992;4:64-66.

10. Suzuki S, Utsugisawa K, Nagane Y, Suzuki N. Three types of striational antibodies in myasthenia gravis. Autoimmune Dis 2011;2011:740583. 